\title{
Lung Cancer pTis TNM Finding v8
}

National Cancer Institute

\section{Source}

National Cancer Institute. Lung Cancer pT is TNM Finding v8. NCI Thesaurus. Code C136447.

Lung cancer with a finding of carcinoma in situ. Squamous cell carcinoma in situ (SCIS). Adenocarcinoma in situ (AIS): adenocarcinoma with pure lepidic pattern, $3 \mathrm{~cm}$ or less in greatest dimension. (from AJCC 8th Ed.) 